\title{
The status of Ig loci rearrangements in single cells from different stages of B cell development
}

\author{
Edwin ten Boekel, Fritz Melchers and Antonius Rolink \\ Basel Institute for Immunology, Grenzacherstrasse 487, $\mathrm{CH}-4005$ Basel, Switzerland \\ Key words: $B$ cell development, Ig gene rearrangement, surrogate $L$ chain, $k L / \lambda L$ chain ratio
}

\begin{abstract}
Differential expression of C-kit, CD25 (TAC), surrogate L chain and cytoplasmic $\mu H$ chain, and surface expression of IgM and IgD allows the separation of B220 (CD45 ${ }^{+}$) B cell subpopulations. PCR analyses with DNA of single cells developed by others and by us have been used to monitor the conformation of the Ig $\mathrm{H}$ and $\mathrm{L}$ chain gene loci in these different $\mathrm{B}$ lineage subpopulations. The results of these analyses indicate that $\mathrm{B220}+/ \mathrm{c}-\mathrm{kit}^{+} / \mathrm{CD}^{-} 5^{-}$cells are the precursors of large $\mathrm{B220}^{+} / \mathrm{CD}^{2} 5^{+} / \mathrm{sigM}-$ which, in turn, are the precursors of small $\mathrm{B220}{ }^{+} / \mathrm{CD}^{-} 5^{+} / \mathrm{sigM}^{-}$cells. The

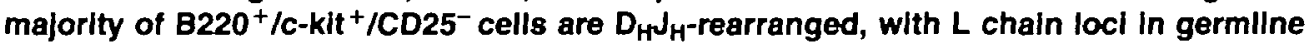

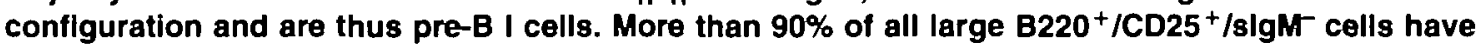
at least one $H$ chaln locus $V_{H} D_{H} J_{H}$ rearranged; half of them have also the second locus $V_{H} D_{H} J_{H}$ rearranged and are thus large pre-B II cells. Rearrangements of at least one allele of the $\mathrm{KL}$ chain locl become detectable in $65 \%$ of the small B220 ${ }^{+} / \mathrm{CD}^{2} 5^{+} / \mathrm{slgM}-$ cells, $67 \%$ of the Immature $\mathrm{B}$ and $>75 \%$ of the mature $B$ cells. The ratio of $k L$ to $\lambda L$ gene rearrangements in all three subpopulations is -10:1, Indicating that the $k \sqcup \lambda L$ ratio is established as soon as rearrangements are made.
\end{abstract}

\section{Introduction}

Bone marrow is the major site of $B$ lymphopoiesis during adult life (1-5). Development from early B-lymphocytelineage-committed progenitors (pro-B) to precursor (pre-B) and immature $B$ cells in mouse bone marrow and to mature, antigen-sensitive $B$ cells in peripheral lymphoid organs can be dissected into different stages. These cellular stages are characterized by the differential expression of surface-located and intra-cellular markers, and by the differential capacities of cells to proliferate 'in vitro' (Fig. 1) (2,5-8). Hardy and his colleagues (6) have used the differential expression of CD43, heat stable antigen (HSA) and BP-1 to separate precursor $\mathrm{B}$ cell subpopulations while our laboratory has employed the analysis of cell size and the expression of c-kit, CD25 (TAC) and surrogate $L(S L)$ chain to do so (7).

Progression along the pathways of $\mathrm{B}$ lymphocyte differentiation is also marked by successive rearrangements of the $\mathrm{Ig}$ gene locl. They begin with $D_{H}$ to $J_{H}$ rearrangements in the $H$ chain gene loci where they appear to involve both alleles within a precursor $B$ cell (9). These so called pro/pre-B I cells express $C$-kit, but not CD25, and are large, cycling cells when prepared 'ex vivo' (7).
$D_{H} J_{H}$ rearrangements are followed by $V_{H}$ to $D_{H} J_{H}$ rearrangements. Cells with productively $V_{H} D_{H} J_{H}$-rearranged Ig $H$ chain alleles, i.e. those capable of expressing a $\mu \mathrm{H}$ chain, appear positively selected over non-productively $V_{H} D_{H} J_{H^{-}}$-rearranged cells (7). This occurs through proliferative expansion of the $\mu \mathrm{H}$ chain-expressing cells, in all likelihood initiated by the signaling through the $\mu \mathrm{H}$ chain/SL chain pre-B receptor (7). Hence, we expect these cells, again, to be large cycling cells. Large, cytoplasmic $\mu \mathrm{H}$ chain expressing cells in bone marrow are c-kit $/ \mathrm{CD} 25^{+}$. About $25 \%$ of them express the $\mu \mathrm{H} / \mathrm{SL}$ pre-B cell receptor which can appear on the surface when the cells are cultured 'in vitro' $(7,10)$.

The next stage of development is thought to be small, resting c-kit $/ \mathrm{CD} 25^{+}$cells expressing cytoplasmic $\mu \mathrm{H}$ chain, but not yet $L$ chains, which are no longer in cell cycle.

$L$ chain expression then leads to deposition of $\operatorname{lgM}$ on the surface of so-called immature B cells. These immature B cells are thought to be the precursors of mature, antigen-sensitive, mitogen-reactive $\operatorname{slgM}^{+} / \mathrm{slgD}^{+} \mathrm{B}$ cells, which are found in part in bone marrow, but are most abundant in peripheral lymphoid organs. 

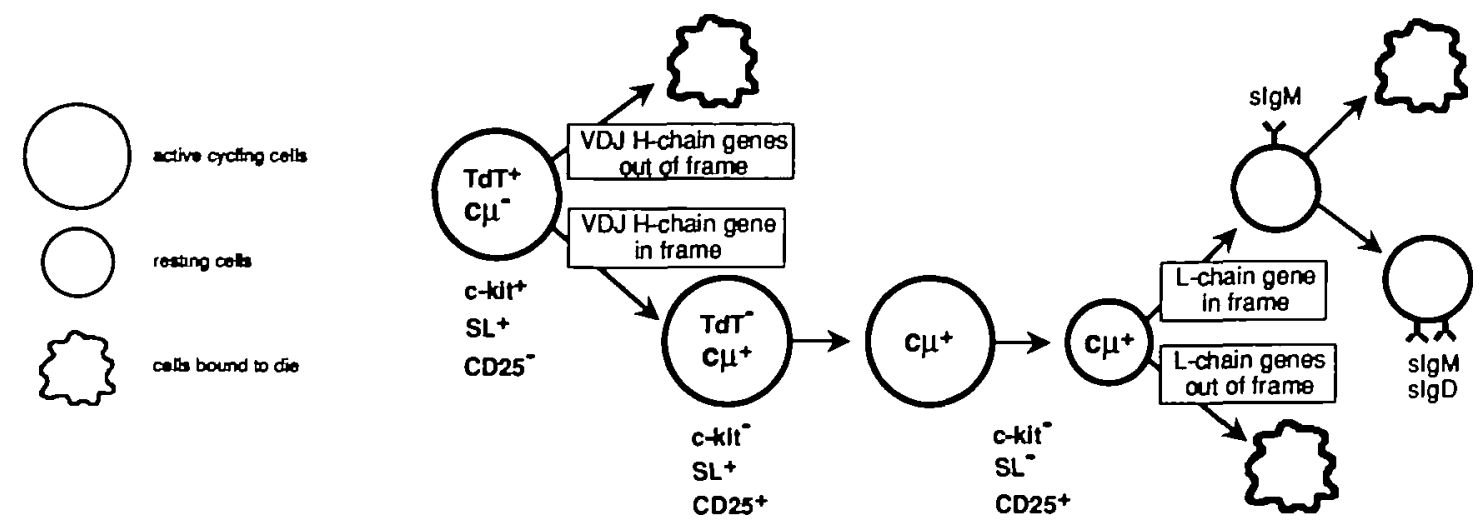

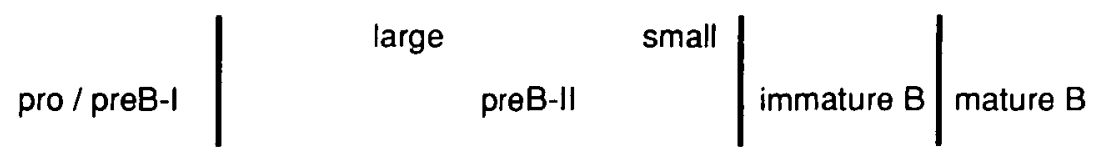

\begin{abstract}
Ig gene rearrangements (results of this study se日 Table 4)
\end{abstract}

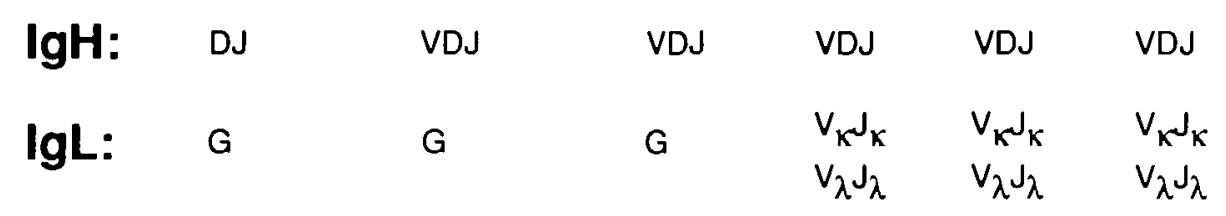

Flg. 1. B lymphopoiesıs in mouse bone marrow, as analyzed by differential marker expression and status of $\lg \mathrm{H}$ and $\mathrm{L} c h a i n$ gene rearrangements.

An assay has been developed by Ehlich et al. (5) that allows the characterizatıon of $\mathrm{lg} \mathrm{H}$ chain gene rearrangements in single cells. This assay has been previously used to monitor the rearrangement status of the Ig gene loci of $B$ lineage precursors in mouse bone marrow characterized, and thus separable, by the differential expression of CD43, HSA and $\mathrm{BP}-1$ (5). We use this assay in the present study to determine the status of $\mathrm{Ig} H$ and $L$ chain gene rearrangements in $B$ lineage precursor cells of mouse bone marrow, as characterized and thus separable by their differences in cell size, and C-kit, CD25, $\mu \mathrm{H} / \mathrm{SL}$ pre-B cell receptor $\lg M$ and $\lg \mathrm{M} / \lg D \mathrm{~B}$ cell receptor expression. The results define the cells in mouse bone marrow in which the majority of either $D_{H}-J_{H}, V_{H}-D_{H} J_{H}$ or $V_{L}-J_{L}$ rearrangements have taken place. The results also allow a comparison with Hardy's bone marrow cell subpopulations defined by CD43, HSA and BP-1 expression, and their status of $\mathrm{Ig}$ gene rearrangements (6). It appears that separation of $\mathrm{B}$ lineage committed cells differentially expressing c-kit, CD25 and SL chain allows a clear distinction and thus purification of precursors before and after productive $V_{H} D_{H} J_{H}$ rearrangements and after $V_{L} J_{L}$ rearrangements.

\section{Methods}

\section{Mice}

(C57BL/6×DBA/2) $F_{1}\left(B_{1} F_{1}\right)$ mice, 6-12 weeks of age, were obtained from the Institut für Biologische-Medizinische Forschung AG (Fülinsdorf, Switzerland).
FACS staining, sort and DNA preparation

Cells for FACS sorting were prepared from bone marrow and spleen as described (7). Bone marrow cells were stained with the FITC-conjugated mAb RA3 6B2 (anti-CD45R, B220) (PharMingen, San Diego, CA) and double stained with biotinconjugated mAb ACK-4 (anti-c-kit) (11), LS156 (anti- $\lambda 5 / \mu \mathrm{H}$ ) (10), $7 D 4$ (anti-CD25, TAC), M41 (anti- $\mu \mathrm{H}$ ) (12) or 1.19 (antiס) (13). Binding of biotin-conjugated $\mathrm{mAb}$ was visualized using streptavidin-phycoerythrin (Southern Biotechnology Associates, Birmingham, AL)

Single cells were sorted using the FACStar Plus equipped with an automatic cell deposition unit (Becton Dickinson, Mountain View, CA). Single cells were directly sorted into 96-well PC plates type $\mathrm{H}$ (Costar, Cambridge, MA) containing $3 \mu \mathrm{l}$ of 10 times concentrated PCR buffer, $7 \mu \mathrm{H} \mathrm{H}_{2} \mathrm{O}$ and $10 \mathrm{ng}$ tRNA. To prepare DNA, samples were overlaid with PCR oil (Fluka, Buchs, Switzerland) and $2 \mu$ l of proteinase $K$ (5 mg/ml; Boehringer, Mannheim, Germany) was added. The samples were digested for $1 \mathrm{~h}$ at $55^{\circ} \mathrm{C}$ and proteinase $\mathrm{K}$ was subsequently inactivated for $10 \mathrm{~min}$ at $95^{\circ} \mathrm{C}$. Plates were then stored at $-70^{\circ} \mathrm{C}$ until use for DNA amplification.

\section{PCR analysis of $\mathrm{Ig} H$ and $L$ gene rearrangements}

PCR amplification was carried out in two rounds using a Hypaid Omnigene PCR machine (Hybaid Ltd, Middlesex, UK). The first round was done over 28 cycles and contained all $5^{\prime}$ and $3^{\prime}$ primers listed in Table 1 as first round primers. The PCR amplification conditions were as described by Ehlich 
Table 1. Oligonucleotides used for amplification of rearranged $\lg \mathrm{H}$ and $\mathrm{L}$ genes

\begin{tabular}{|c|c|c|c|c|}
\hline \multirow[t]{2}{*}{ Sequence } & \multirow[t]{2}{*}{ Specificity } & \multirow[t]{2}{*}{ Ref. } & \multicolumn{2}{|c|}{ PCR round usage } \\
\hline & & & First & Second \\
\hline \multicolumn{5}{|l|}{$5^{\prime}$ primers } \\
\hline GCGAAGCTTA(AG)GCCTGGG(AG)CTTCAGTGAAG & $V_{H} J 588$ & (5) & + & + \\
\hline GCGAAGCTTCTCACAGAGCCTGTCCATCAC & $\mathrm{V}_{\mathrm{H}} \mathrm{O} 52$ & (5) & + & + \\
\hline GCGAAGCTITCTCAG(AT)CTCTGTC(CT)CTCACC & $V_{H} 36-60$ & (5) & + & + \\
\hline GCGAAGCTTCTCGAGTCTGGAGGTGGCCTG & $V_{H} \times 24$ & (5) & + & + \\
\hline GCGAAGCTTGTGGAGTCTGGGGGAGGCTTA & $V_{H} 7183$ & (5) & + & + \\
\hline GCGAAGCT(AT)CTGGAGGAGGCTTGGTGCAA & $V_{H} J 606, V_{H} S 107, V_{H} \times 24$ & (5) & + & + \\
\hline GCGAAGCTTGGAGAGACAGTCAAGATCTCC & $V_{H} G A M 3$ & (5) & + & + \\
\hline CACAGAGAATTCTCCATAGTTGATAGCTCAG & $\mathrm{D}_{\mathrm{H}} \mathrm{Q} 52$ & & + & - \\
\hline GCCTCAGAATTCCTGTGGTCTCTGACTGGT & $\mathrm{D}_{\mathrm{H}} \mathrm{Q} 52$ & & - & + \\
\hline ACAAGCTTCAAAGCACAATGCCTGGCT & $\mathrm{D}_{\mathrm{H}} \mathrm{FL} 16, \mathrm{D}_{\mathrm{H}} \mathrm{SP} 2$ & (2) & + & - \\
\hline ACGTCGACTTTTGT(GC)AAGGGATCTACTACTGT & $\mathrm{D}_{\mathrm{H}} \mathrm{FL} 16, \mathrm{D}_{\mathrm{H}} \mathrm{SP} 2$ & (5) & - & + \\
\hline GGAGAGAGTITAGTATAGGAACACAGAGGC & $5^{\prime}$ of $J_{H} 1$ & & + & + \\
\hline GGCTGCAG(CG)TTCAGTGGCAGTGG(AG)TC(AT)GG(AG)AC & $V_{k}$ & $(15)$ & + & + \\
\hline GCTACCCACTGCTCTGTTCCTCTTCAGTG & $5^{\prime}$ of $J_{k} 1$ & & + & + \\
\hline GCCATTTCCCAGGCTGTTGTGACTCAGG & $V_{\lambda}$ & & + & - \\
\hline AATCTGCACTCACCACATCACCTGGTG & $\hat{v_{\lambda}}$ & & - & + \\
\hline \multicolumn{5}{|l|}{$3^{\prime}$ prımers } \\
\hline AGGCTCTGAGATCCCTAGACAG & $3^{\prime}$ of $J_{H^{4}}$ & (5) & + & - \\
\hline GGGTCTAGACTCTCAGCCGGCTCCCTCAGGG & $3^{\prime}$ of $J_{H^{4}}$ & (5) & - & + \\
\hline CAAAACCCTCCCTAGGTAGACAATTATCCCTC & 3 of $J_{x^{2}}$ & & + & - \\
\hline ССТCTCAACTAAAGCCTCПIITGCСССТAATC & $3^{\prime}$ of $J_{x} 5$ & & + & - \\
\hline ACTCACCTAGGACAGTCAGCTTGGTTCC & & & + & + \\
\hline GGACAGATCTCCCTCCTTAACACCTGATCTG & $3^{x}$ of $J_{x} 2$ & & - & + \\
\hline CATAACTGACTGTGCTGGCTGGGTTGG & RS & & + & - \\
\hline CTGCCCACACGACTCCTTCAGGCAGACG & RS & & - & + \\
\hline ATGCGACGTCAACTGATAATGAGCCCTCTCC & $3^{\prime}$ of $J_{k} 5$ & & - & + \\
\hline
\end{tabular}

et al. (5). For the second PCR round, $1 \mu$ of the first PCR amplification was reamplified with one specific $5^{\prime}$ primer and a specific $3^{\prime}$ primer (Table 1, second round PCR primers). The second round was done over 35 cycles $\left(20 \mathrm{~s}\right.$ at $95^{\circ} \mathrm{C}$, $1 \mathrm{~min}$ at $65^{\circ} \mathrm{C}, 2 \mathrm{~min}$ at $72^{\circ} \mathrm{C}$ ). All PCR contained dATP, dCTP, dTTP and dGTP (Pharmacia, Uppsala, Sweden) at $200 \mu \mathrm{M}$ each and $5 \cup$ Taq DNA polymerase (Roche, Basel, Switzerland) in PCR buffer $(0.05 \mathrm{mM}$ 2-mercaptoethanol, $50 \mathrm{mM} \mathrm{KCl}, 10 \mathrm{mM}$ Tris- $\mathrm{HCl}, \mathrm{pH} 8.3,1.5 \mathrm{mM} \mathrm{MgCl}_{2}$ and $0.001 \%$ gelatine). The first round PCR reaction was performed in $30 \mu \mathrm{l}$, the second in $20 \mu \mathrm{l}$. Then, $10 \mu \mathrm{l}$ of the second round PCR product was analyzed on agarose gels stained with ethidium bromide. The lengths of the different PCR products are summarized in Table 2.

\section{Results and discussion}

PCR assay for the analyses of $1 g$ gene rearrangements in single cells

We have used assays for $H$ chain gene rearrangements developed by Ehlich et al. (5) and by Haasner et al. (14), and assays for $\mathrm{KL}$ chain gene rearrangements developed by Schlissel and Baltimore (15), and have modified and extended these assays, particularly to include $\lambda L$ chain gene rearrangements, as described in Methods. At the single cell level, these assays are based on PCR amplification of gene segments in two steps. In the first, both rearranged Ig loci of a cell were amplified simultaneously using a mixture of $135^{\prime}$ primers, homologous to $V_{H}, V_{L}$ and $D_{H}$ genes, and upstream of the
Table 2. Approximate PCR product lengths

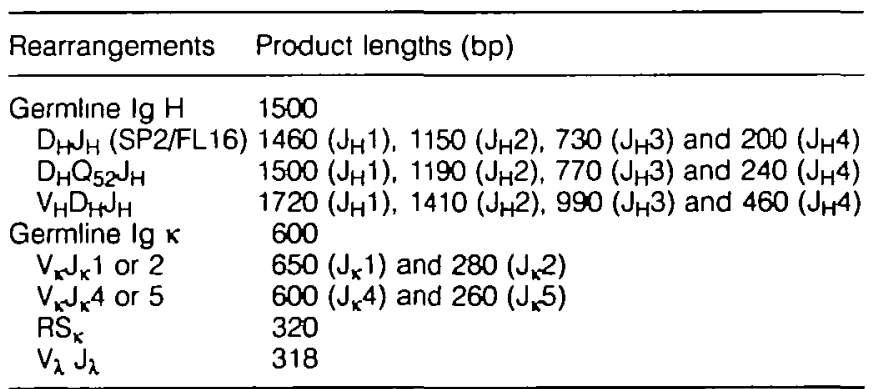

$J_{H} 1$ and $J_{L_{k}} 1$ segment in combination with five $3^{\prime}$ primers binding downstream of $J_{H} 4, J_{L \kappa} 2, J_{L \kappa} 5, J_{L \lambda}$ and $R S_{\kappa}$. The primers are listed in Table 1 . In the second PCR round, the products of the first PCR were analyzed in separate reactions. For VDJ and DJ PCR, each reaction contained respectively a single $V_{H}$ and $D_{H}$ primer together with a nested $3^{\prime} J_{H} 4$ primer. The unrearranged state of an $\mathrm{lg} \mathrm{H}$ locus was determined by the reaction containing a primer recognizing $5^{\prime}$ of the $J_{H} 1$ segment and a nested $3^{\prime} J_{H} 4$ primer. PCR assays for $L_{k}$ chain rearrangements used a $V_{k}$ consensus primer located at the $5^{\prime}$ end of framework 3 , as well as two primers in the $J_{k}$ locus; $J_{x} 1-2$ and $J_{x} 4-5$, located downstream of $J_{x} 2$ and $J_{k} 5$ respectively. In the second PCR step, a nested primer (upstream) of primer $J_{x} 1-2$ and $J_{k} 4-5$ was used. We used two different $J_{k}$ primers in the first $P C R$, because amplification 
of $V-J_{k} 1$ and $V-J_{k} 2$ rearrangements by using the $J_{k} 4-5$ primer only resulted in a low frequency of $J_{k} 1$ and $J_{k} 2$ rearrangement (results not shown). The $\lambda$ PCR assay utilized a $V_{\lambda}$ consensus primer and a universal $J_{\lambda}$ primer in the furst PCR round and a nested $V_{\lambda}$ primer together with the universal $J_{\lambda}$ primer in the second PCR round. It has been described that expression involving $J_{\lambda} 1$ segments occurs 10 times more frequently than $J_{\lambda} 2$ and 3 whereas expression of $J_{\lambda} 4$ was undetectable (16). Therefore we used a $J_{\lambda}$ primer which binds to $J_{\lambda} 1$, rather than $J_{\lambda} 2,3$ and 4 genes. Thus, we cannot exclude that some $\lambda$ rearrangements are not detectable in these assays.

\section{Ig $H$ and $L$ chain gene rearrangements in $B$ cell sub- populations}

A total of 24 single $\mathrm{B}_{2} 20^{+} /{\mathrm{c}-\mathrm{kit}^{+}}^{+}$cells, 48 single large $\mathrm{B} 22 \mathrm{O}^{+} /$ $\mu \mathrm{H} / \mathrm{SL}^{+}$cells, 48 single large $\mathrm{B} 22 \mathrm{O}^{+} / \mathrm{CD}^{+} 5^{+} / \mathrm{slgM}$ cells, 48 single small $\mathrm{B} 220^{+} / \mathrm{CD}^{2} 5^{+} / \mathrm{slgM}^{-}$cells, 48 single immature $\mathrm{B}$ cells and 44 single mature $B$ cells were sorted as described in Methods, and analyzed for the status of their two $\operatorname{lg~} \mathrm{H}, \mathrm{kL}$ and $\lambda L$ chain alleles. A representative picture of $V_{H} J 558-$ $D_{H} J_{H}$ rearrangements and $V_{K} J_{K} 1$ or 2 rearrangments found in single Immature $B$ cells is shown in Fig. 2.

$H$ chain alleles. In $42 \%$ of the cells, both $\lg H$ alleles were detected and in $36 \%$ of the cells only a single PCR product was observed. No amplification was obtained in $22 \%$ of the tested cells. However, it should be noted that cells containing certaın combinations of rearrangements in Ig $\mathrm{H}$ loci might be under-represented Due to the recognition of $D_{\mathrm{FL}}$ and $D_{\mathrm{SP}}$ segments by the same primer, the present assay does not resolve two $D J_{H}$ joints involving $D_{H}$ elements of these two families rearranged to the same $J_{H}$ genes on both chromosomes, because these rearrangements will appear as a sıngle PCR band. Moreover, two $V_{H} D J_{H}$ joints involving $V_{H}$ genes of the same family rearranged to the same $J_{H}$ gene on both chromosomes cannot be discriminated on the gel. Furthermore, the $D_{\text {SP,FL }}$ primer does not bind to the FL16.2 segment Hence, $\sim 7 \%$ of the $D J_{H}$ rearrangements will not be scored, assuming that the usage of the $D$ segments in rearrangements is random, as suggested earlier (17).

The results of the analyses of the $H$ chain alleles in single cells of different stages of B cell development are given in Tables 3 and 4 . They show that the majority of all $\mathrm{H}$ chain alleles in $B 220^{+} / \mathrm{c}-\mathrm{kit}^{+}$cells are $\mathrm{D}_{\mathrm{H}} \mathrm{J}_{\mathrm{H}^{-}}$, but not yet $\mathrm{V}_{\mathrm{H}} \mathrm{D}_{\mathrm{H}^{-}} \mathrm{J}_{\mathrm{H}^{-}}$ rearranged and are thus pre- $\mathrm{B} /$ cells. This is in agreement with previous analyses from our laboratory either on $\mathrm{B} 22 \mathrm{O}^{+} /$ $\mathrm{c}^{\mathrm{k}} \mathrm{kit}^{+}$cell populations obtained 'ex vivo' $(8,14)$ or detected in lines and clones of $\mathrm{B}^{2} 2 \mathrm{O}^{+} / \mathrm{c}-\mathrm{kit}^{+}$cells proliterating on stromal cells in the presence of IL7 $(8,14)$.

$V_{H} D_{H} J_{H}$-rearranged alleles are detected at equally high frequencies in $\mathrm{B} 22 \mathrm{O}^{+} / \mu \mathrm{H} / \mathrm{SL}^{+}$, large and small $\mathrm{B} 220^{+} / \mathrm{CD}^{2} 5^{+} /$ slgMt, immature $B$ and mature $B$ cells. More than $90 \%$ of the PCR positive cells of these showed at least one $\mathrm{H}$ chain allele in the $V_{H} D_{H} J_{H}$-rearranged configuration. This is in agreement with the observation that $>90 \%$ of all large and small $\mathrm{B} 22 \mathrm{O}^{+}$I $\mathrm{CD}^{2} 5^{+} / \mathrm{slgM}^{-}$cells express $\mu \mathrm{H}$ chains in their cytoplasm (7).

Among the cells in which both alleles were detectable, $\sim 50 \%$ had both alleles $V_{H} D_{H} \jmath_{H}$ rearranged while the other $50 \%$ was $V_{H} D_{H} J_{H} / D_{H} J_{H}$ rearranged. Again, this was true for

\section{A}
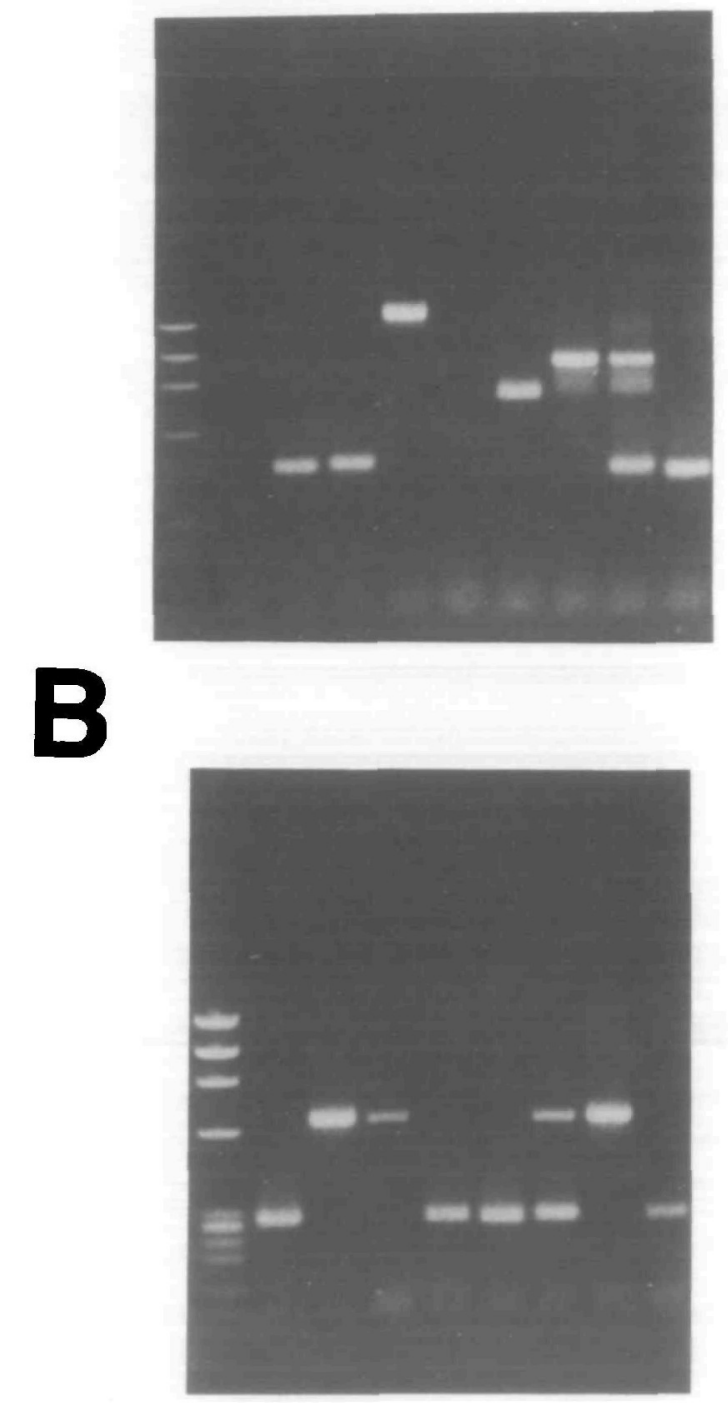

Flg. 2. A representative example of $V_{H} J 558-D_{H} d_{H}$ rearrangments (A) and $V_{k} J_{k} 1$ or 2 rearrangements $(B)$ as found in eight single immature $B$ cells (lanes 2-9) Molecular weight markers are shown in lane 1.

$\mathrm{B} 220^{+} / \mu \mathrm{H} / \mathrm{SL}^{+}$large and small $\mathrm{B}^{+} 20^{+} / \mathrm{CD} 25^{+} / \mathrm{slgM}^{-}$, immature $\mathrm{B}$ and mature $\mathrm{B}$ cells (Table 3 ). These results agree with and extend the observation that $40 \%$ of the peripheral $B$ cells have both $H$ chain alleles in a $V_{H} D_{H} J_{H}$-rearranged configuration (18). Future sequencing of all alleles should answer the question of which alleles are, or are not, productively $V_{H} D_{H} d_{H}$ rearranged, and quantitate the reading frame distribution amongst $D_{H} J_{H}$ rearranged $H$ chain alleles $(5,14,19)$. They will also allow an investigation of the usage of $V$ gene segments in the $H$ chain alleles of different $B$ cell subpopulations during development.

$L$ chain alleles. Approximately $40 \%$ of $V_{k}$ genes rearrange by inversion (20), thus retaining previous rearrangements on the same chromosome. In addition, any excised DNA containing 
Table 3. Configuration of $\lg \mathrm{H}$ loci in pro/pre-B I, pre-B II, immature and mature B cells

\begin{tabular}{|c|c|c|c|c|c|c|}
\hline & \multicolumn{6}{|c|}{$B$ cell subpopulations ${ }^{a}$} \\
\hline & $\mathrm{c}-\mathrm{kIt}^{+} / \mathrm{CD} 25^{+}$ & $\begin{array}{l}\mathrm{c}-\mathrm{kit}^{+} / \mathrm{CD} 25^{+} / \mathrm{SL} / \mu \mathrm{H}^{+} \\
\text {large }\end{array}$ & $\begin{array}{l}\mathrm{c}-\mathrm{kit} / \mathrm{CD} 25^{+} / \mathrm{slgM} \\
\text { large }\end{array}$ & $\begin{array}{l}\mathrm{c}-\mathrm{kit}^{-} / \mathrm{CD}_{2} 5^{+} / \mathrm{slgM} \\
\text { small }\end{array}$ & $\lg ^{+} B$ & $\operatorname{lgM}^{+} / \lg ^{+} B$ \\
\hline $\begin{array}{l}\text { Total no. of cells tested } \\
\text { No. of cells with }\end{array}$ & 24 & 48 & 48 & 48 & 48 & 44 \\
\hline VDJNDJ & 1 & 12 & 7 & 12 & 6 & 5 \\
\hline VDJ/DS & 2 & 13 & 9 & 12 & 11 & 7 \\
\hline DJ/DJ & 8 & 2 & 0 & 0 & 0 & 0 \\
\hline GLNDJ & 0 & 2 & 2 & 0 & 0 & 0 \\
\hline VDJ/- & 0 & 8 & 3 & 12 & 18 & 18 \\
\hline DJ/- & 8 & 2 & 11 & 5 & 3 & 2 \\
\hline$\%$ & 5 & 9 & 16 & 7 & 10 & 12 \\
\hline
\end{tabular}

aAll subpopulatıons are B220 (CD45R) ${ }^{+}$

$b_{-:}$one or two alleles not detected.

Table 4. The rearrangement status of $\lg \mathrm{H}$ and $\mathrm{L}$ chain alleles of single cells at different stages of development

\begin{tabular}{|c|c|c|c|c|c|c|c|}
\hline & \multicolumn{7}{|c|}{ B cell subpopulations ${ }^{a}$} \\
\hline & $\mathrm{c}-\mathrm{kit}^{+} / \mathrm{CD} 25^{-}$ & $\begin{array}{l}\text { c-kit } / \mathrm{CD} 25^{+} / \mathrm{SL} / \mu \mathrm{H}^{+} \\
\text {large }\end{array}$ & $\begin{array}{l}\mathrm{c}-\mathrm{kit}^{-} / \mathrm{CD}_{25} 5^{+} / \mathrm{slgM} \\
\operatorname{large}\end{array}$ & $\begin{array}{l}\mathrm{c}-\mathrm{kIt}^{\prime} / \mathrm{CD} 25^{+} / \mathrm{slgM}- \\
\text { small }\end{array}$ & $\lg ^{+} B$ & $\operatorname{lgM}^{+} / / g D^{+} B$ & $\operatorname{lgM}^{+} \lg D^{+} \lambda L^{+} B$ \\
\hline \multicolumn{8}{|c|}{ Configuration of Ig $\mathrm{H}$ chain alleles } \\
\hline germlıne & 0 & 2 & 2 & 0 & 0 & 0 & $N D^{b}$ \\
\hline$D_{H} J_{H}$ & 26 & 19 & 20 & 17 & 14 & 9 & ND \\
\hline$V_{H} D_{H} J_{H}$ & 4 & 46 & 28 & 48 & 41 & 35 & ND \\
\hline efficiency of detection & $63 \%$ & $70 \%$ & $52 \%$ & $68 \%$ & $57 \%$ & $50 \%$ & - \\
\hline \multicolumn{8}{|c|}{ Configuration of Ig $L$ chain alleles } \\
\hline germline $\alpha L$ & ND & ND & ND & 20 & 26 & 23 & 2 \\
\hline$V_{k} J_{k}$ & 0 & 1 & 1 & 47 & 50 & 47 & 36 \\
\hline$V_{\lambda} J_{\lambda}$ & 0 & 0 & 0 & 6 & 4 & 6 & 36 \\
\hline RS & ND & ND & ND & ND & ND & ND & 22 \\
\hline
\end{tabular}

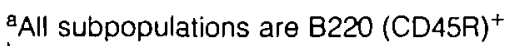

bND. not done.

the 'germlıne fragment' $\left(J_{k} 1-J_{k} 2\right.$ region) or primary $V_{k} J_{k}$ rearrangements may still be present in the cell and thus be available for PCR amplification, since we employed an oligonucleotide $\left(J_{k} 1-2\right)$ priming inside the $J_{k}$ cluster. When an inverted $V_{k}$ gene or a non-inverted $V_{k}$ gene joins to $J_{k} 4$ or 5 , the germline fragment is retained in the same chromosome in the former case and is deleted in the latter. Hence, when a secondary (inversional) rearrangement has occurred, more than two PCR bands can be found. The numbers of alleles given in Table 4 as the results of the analyses of the $\kappa L$ chain alleles in different $B$ cell subpopulations make the assumption that only one cell with maximally two $\kappa L$ chain alleles was analyzed in each assay. Hence, in cases where more than two PCR products of the $k L$ chain locus were detectable (in fact in 12 of a total of 164 cells with detectable $\mathrm{kL}$ chain loci), they were counted as two alleles.

Of the $24 \mathrm{~B}^{2} 20^{+} / \mathrm{c}-\mathrm{kit}^{+}$cells, $48 \mathrm{B220}+\mu \mathrm{H} / \mathrm{SL}^{+}$cells and

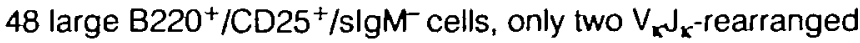
alleles were detectable (Table 4). This shows that the vast majority of precursor $B$ cells rearrange the $D_{H}-J_{H}$ and $V_{H^{-}}$ $D_{H} J_{H}$ segment on the $H$ chain loci before they rearrange the
$L$ chain loci. It makes the possible alternate pathway of $B$ cell development improbable, or at least infrequent (21). While the large $\mu \mathrm{H} / \mathrm{SL}^{+}$and $\mu \mathrm{H} / \mathrm{SL}^{-}$pre-B II cells are both candidates for precursor of small pre-B II cells, it remains to be investigated whether both of them, or only one of them, play(s) this role in $\mathrm{B}$ cell differentiation.

Rearrangements of at least one allele of the $\mathrm{KL}$ chain gene locus became detectable in $65 \%$ of the small $\mathrm{B} 220^{+} / \mathrm{CD} 25^{+}$I sigM- cells, in $67 \%$ of the immature $B$ and in $>75 \%$ of the mature $B$ cells (data for single cells not shown, but summarized as numbers of alleles in Table 4). This indicates that $\kappa L$ chain gene rearrangements are induced when small resting $\mathrm{B} 220^{+} / \mathrm{CD}^{2} 5^{+} / \mathrm{slgM}^{-}$cells develop and suggests that large $\mathrm{B} 220^{+} / \mathrm{CD}^{2} 5^{+} / \mathrm{slgM}^{-}$cells are the precursors of their small counterparts. Collectively, these results define c-kit ${ }^{+} \mathrm{CD}_{25}$ cells as mostly $D_{H} J_{H}$-rearranged pre-B I cells and which are the precursors of large c-kit $/ \mathrm{CD} 25^{+} / \mu \mathrm{H} / \mathrm{SL}^{+1-} V_{\mathrm{H}} \mathrm{D}_{\mathrm{H}} \mathrm{H}^{-}$ rearranged preB $\|$ cells, which are the precursors of the small c-kit $/$ CD25 $5^{+} / \mu \mathrm{H} / \mathrm{SL}^{-}-V_{H} \mathrm{D}_{H} \mathrm{~J}_{H} \mathcal{N}_{\mathrm{L}} \mathrm{J}_{\mathrm{L}}$-rearranged pre-B II cells, which, in turn, are the precursors of the $\operatorname{sigM}^{+}$immature $B$ cells. 


\section{Rearrangements in $\mathrm{kL}$ versus $\lambda L$ gene locı}

The majority of the $L$ chain rearrangements are found in the $\kappa$ loci. The ratio of rearrangements in the $k \mathrm{~L}$ versus $\lambda \mathrm{L}$ chain is $10: 1$ (Table 3 ). This ratio is stable throughout the different $B$ lineage populations with increasing maturity, i.e. from small $\mathrm{B} 220^{+} / \mathrm{CD}^{2} 5^{+} / \mathrm{slgM}^{-}$to immature $\mathrm{B}$ to mature $\mathrm{B}$ cells. The majority of $V_{k} J_{k}$-rearranged small pre-B $I I$, immature $B$ and mature $B$ cells do not have $\lambda L$ chain gene rearrangements. However, 12 of the 16 cells with $\lambda L$ gene rearrangements have $V_{k} J_{k}$ rearrangements using the most $3^{\prime} J_{k} 5$ segment.

Furthermore, mature $\lambda L$ chain-producing $B$ cells from spleen were analyzed for the configurations of their $L$ chain alleles (Table 4 , last column). A rearranged $\lambda L$ locus was detected in all $\lambda$-producing $B$ cells Although we have not yet ruled out by sequencing that all 36 cells analyzed (Table 4 ) produced $\lambda_{1} L$ chain, we take this as a strong indication that the $\lambda$ PCR assay is very efficient and can probably detect rearrangements in all the $\lambda L$ chasn locı. Moreover, all $\lambda L$-producing cells showed rearrangements in their $k L$ chain loci Twentynine of the 36 cells analyzed, again, had $V_{x} J_{\kappa}$ rearrangements using $\mathrm{J}_{\mathrm{K}} 5$.

These findings are consistent with previous reports $(22,23)$. However, $\lambda L$ chain gene-rearranged $B$ cells in which no $\kappa \mathrm{L}$ chain gene rearrangements were detectable have been described (24). While this might imply that some $\lambda L$ chainexpressing cells have their $\mathrm{KL}$ chain loci in germlıne configuratIon, the more frequently observed $V_{\lambda} J_{\lambda}$-rearranged pre- $B$ II cells (five of six), immature $B$ cells (two of four) or mature $B$ cells (seven of eight), is one in which $k L$ chain gene loci are rearranged to downstream $J_{x}$ segments or even deleted via RS. In fact, deletion was observed in 22 of the $36 \lambda \mathrm{L}$ chain ${ }^{+} \operatorname{slg}^{+} B$ cells (Table 4 , last column). In addition, due to the complexity of the $\kappa L$ chain gene locus introduced by opposite polarities of $V_{\kappa}$ segments, it is not even certain that the $\lambda L$ chain-rearranged cells, in which no $k L$ chain rearrangements were observed, have, in fact, these $\mathrm{kL}$ chain loci in germline configuration.

All these results suggest that the $\kappa L / \lambda L$ chain ratio of the mature peripheral $B$ cell pool, which also is of the order of $10: 1$, is established as soon as $L$ chain gene rearrangements are induced, i.e. in the pre-B II cells. It will require the analysis of a much larger number of cells from the different $B$ lineage compartments in bone marrow and the sequencing of the rearranged $\lg L$ chain loci to determine whether this ratio is exactly the same in all stages of B cell development with rearranged $L$ chain loci or whether selective forces on a small number of the total cells influence this ratio with increasing maturity. It is also too early to conclude from our data that all $\lambda L$ chain rearrangements obligatorily follow $k L$ chain rearrangements, although the majority of them appear to do so.

Finally, since small pre-B II cells do not deposit IgM on the surface and since $L$ chains so far have not been detectable in the cytoplasm by immunofluorescence with specific antibodies (while $\mu \mathrm{H}$ chains are easily detectable), it might well be that $\kappa L$ chain gene rearrangements and the expression of the rearranged $L$ chain loci as proteins are separately regulated. One possible example of such a cell with rearranged $\mathrm{xL}$ chain loci but without expression of the rearranged gene locus is the $70 Z / 3$ preB lymphoma (25).
A comparision of the B-lineage-committed, CD45RA $\left(B 22 \mathrm{O}^{+}\right)$ subpopulations of bone marrow characterized by different markers in different laboratories

Hardy's (6) and Rajewsky's (5) laboratories have used the differential expression of CD43, HSA and BP-1 to separate CD45RA $\left({\left.\mathrm{B} 220^{+}\right)}\right.$B-lıneage-committed precursors into fractions $B, C, C^{\prime}$ and $D$, and into the immature and mature, $\operatorname{slgM}^{+} / \mathrm{s} \lg \mathrm{D}^{-}$and $\operatorname{slgM}^{+} / \mathrm{sigD}^{+}$populations $\mathrm{E}$ and $\mathrm{F}$. Analyses of the status of the $\mathrm{Ig}$ gene loci in these fractions have shown that fraction $B$ is enriched for $D_{H} J_{H^{-}}$rearranged $H$ chain loci which have not yet undergone $V_{H} D_{H} J_{H}$ rearrangements. Fraction $B$ is therefore likely to be largely the same as our pro/pre-B I population (Fig. 1). Fraction $\mathrm{C}$ was found to be enriched for cells with two non-productively $V_{H} D_{H^{-}} N_{H^{-}}$ rearranged $\mathrm{lg} \mathrm{H}$ alleles. We have hypothesized (see Fig. 1) but never detected these cells in our assays.

Ehlich et al. (5) have suggested that fractions $C^{\prime}$ and $D$ might have similar $\mathrm{lgH}$ rearrangements. They therefore only analyzed fraction $\mathrm{D}$ and found all cells to contain one productively $V_{H} D_{H} J_{H^{-r e a r r a n g e d ~}} \mathrm{gH}$ allele. Fractions $C^{\prime}$ and $D$ could therefore be, at least in part, the same as the large, $\mu \mathrm{H} / \mathrm{SL}^{+}$ and $\mu \mathrm{H} / \mathrm{SL}^{-}$pre-B I| cells, and the small pre-B II cells In our analyses, $60 \%$ of the large pre-B $\|$ cells and $30 \%$ of the small pre-B II cells express BP-1 (7), indicating that the comparison of fractions $C^{\prime}$ and $D$ with pre-B II cells is complicated. Also, fractions $C^{\prime}$ and $D$ include to a good part the large, cycling cells that should contain the large, $\mu \mathrm{H} / \mathrm{SL}^{+}$ and $\mu \mathrm{H} / \mathrm{SL}^{-}$pre-B II cells. Our scheme of separation on the basis of large, cycling and small, resting cells, as well as the patterns of expression of c-kit, CD25 and SL and the analysis of the rearrangement status of $L$ chain gene loci appears to allow a better resolution of crucial steps in the development of precursor $B$ cells, especially since $L$ chain gene rearrangements are almost totally absent in large pre-B II cells and appear in full when they become resting, small pre-B II cells. With all the analyses on marker expression and status of $\mathrm{lg}$ gene loci rearrangements, we should now be in the position to simplify the nomenclature of precursor B cells in bone marrow and to propose protocols for the analysis of precursor $B$ cell compartments that might vary in their contents due to genetic or environmental influences. More importantly, we are now in a position to clearly separate cells with defined stages of Ig gene rearrangements according to their cellular program of differentiation, i.e. marker expression. This will facilitate the generation of differential cDNA libraries in the search for genes and molecules which control these B cell developmental steps.

\section{Acknowledgements}

The able technical assistance of Andrea Groenenwegen and Marc Dessing is gratefully acknowledged. We thank Drs Klaus Karjalainen and Thomas Winkler for critical reading of our manuscript. The Basel Institute for Immunology was founded and is supported by $F$. Hoffmann-La Roche Ltd. Basel, Switzerland.
Abbreviations
HSA heat stable antigen
RS recombination signal sequence (up- and downstream.
SL of $\mathrm{CK}$ ) surrogate light chain 


\section{References}

1 Rolink, A. and Melchers, F. 1992. Molecular and cellular origins of B tymphocyte diversity. Cell 66:1081.

2 Rolink, A., Haasner, D., Nishikawa, S I. and Melchers, F. 1993. Changes in frequencies of clonable preB cells during life in different lymphoid organs of mice. Blood 81.2290 .

3 Osmond, D G 1990. B cell development in bone marrow. Semin. Immunol. 2:173.

4 Osmond, D. G., Kim, N, Manoukıan, R., Phillips, R A., RicoVargas, S. A. and Jacobsen, K. 1992. Dynamics and localization of early B-lymphocyte precursor cells (pro-B cells) in the bone marrow of scid mice. Blood 79:1695

5 Ehlich, A., Martin, V. Müller, W. and Rajewsky, K. 1994 Analysis of the B-cell progenitor compartment at the level of single cells. Curr. Biol. 4:573.

6 Hardy, R. R., Carmack, C E., Shınton, S. A., Kemp, J. D. and Hayakawa, K. 1991. Resolution and characterization of proB and pre-pro $B$ cell stages in normal mouse bone marrow. J. Exp. Med. 173:1213.

7 Rolink, A., Grawunder, U., Winkler, T. H., Karasuyama, H. and Melchers, F 1994 IL-2 receptor $\alpha$ chain (CD25, TAC) expression defines a crucial stage in preB cell development int immunol 6.1257 .

8 Rolink, A., Kudo, A., Karasuyama, H., Kikuchi, Y. and Melchers, F. 1991. Long-term proliferating early preB cell lınes and clones with the potential to develop to surface-lg positive mitogenreactive B cells 'in vitro' and 'in vivo' EMBO J 10.327.

9 Tonegawa, S. 1983. Somatic generation of antibody diversity. Nature 302:575

10 Winkler, T. H., Rolink, A. G., Melchers, F and Karasuyama, H. 1995. Precursor $B$ cells of mouse bone marrow express two different complexes with the surrogate light chain on the surface. Eur. J. Immunol, in press

11 Ogawa, M., Matzusakı, Y., Nıshıkawa, S , Hayashı, S. I., Kunısada, T., Sudo, T., Kina, T., Nakauchi, H. and Nishikawa, S. I. 1991. Expression and function of c-kıt in hemopoietic progenitor cells J. Exp Med. 174.63.

12 Leptin, M. 1985 Monoclonal antıbodies specific for murine IgM.II. Activation of B lymphocytes by monoclonal antibodies specific for the four constant domains of IgM. Eur. J. Immunol. 15:131.

13 Parkhouse, R. M. E., Preece, G., Sutton, R. Cordell, J. L and Mason, D. Y. 1992. Relative expression of surface IgM, IgD and the Ig-associating $\alpha$ (mb-1) and $\beta$ (B-29) polypeptide chains. Immunology 76:535

14 Haasner, D., Rolink, A. and Melchers, F. 1994. Influence of surrogate $L$ chain on DHJH-reading frame 2 suppression in mouse precursor $\mathrm{B}$ cells Int. Immunol 6:21

15 Schlissel, M. S. and Battimore, D. 1989. Activation of immunolghobulin $x$ gene rearrangement correlates with induction of germline $\kappa$ gene transcription. Cell 58:1001.

16 Miller, J., Selsin, E. and Storb, U. 1982. Structural alterations in regions of mouse immunoglobulin $\lambda$ genes are associated with differential gene expression. Nature 295.428 .

17 Bangs, L. A., Sanz, I. E. and Teale, J. M 1991 Comparison of $\mathrm{D}, \mathrm{JH}$ and junctional diversity in the fetal, adult, and aged $\mathrm{B}$ cell repertoires. J. Immunol. 146:1996

18 Alt, F W., Blackwell, T. K., Depinho, R. A., Reth, M. G. and Yancopoulos, G D. 1986 Regulation of genome rearrangement events during lymphocyte differentration. Immunol. Rev 89:5.

$19 \mathrm{Gu}, \mathrm{H}$., Kitamura, D. and Rajewsky, K 1991. B cell development regulated by gene rearrangement: arrest of maturation by membrane-bound $D_{\mu}$ protein and selection of $D_{H}$ element reading frames. Cell 65:47.

20 Shapıro, $M$ A. and Weigert, $M$ 1987. How immunoglobulın $V_{k}$ genes rearrange. J. Immunol. 139:3834.

21 Kubagawa, H., Cooper, M. D., Carroll, A. J and Burrows, P. D. 1989. Light-chain gene expression before heavy-chain gene rearrangement in preB cells transformed by Epstein-Barr virus. Proc Natl Acad Sci. USA 86.2356.

22 Coleclough, C 1990 A critique of the Cohn-Langman protecton theory Immunol. Rev. 115:173.

23 Hieter, P. A., Korsmeyer, S J., Waldmann, T. A. and Leder, P 1981. Human immunoglobulin $\kappa$ light chain genes are deleted or rearranged in $\lambda$ producing $B$ cells. Nature 290:368.

24 Berg, J, McDowell, M., Jack, H. M. and Wabl, M. 1990 Immunoglobulin $\lambda$ gene rearrangement can precede $\kappa$ gene rearrangement Dev. Immunol. 1:53

25 Paıge, C., Kıncade, P. and Ralph, P. 1978. Murıne B cell leukemia line with inducible surface immunoglobulin expression. $J$. Immunol. 121:641. 